\title{
Understanding the Path Toward Family Economic Well- Being of Coconut Growers
}

\author{
Rusitha Wijekoon, Mohamad Fazli Sabri, Nobaya Ahmad \& Husniyah Abdul \\ Rahim
}

To Link this Article: http://dx.doi.org/10.6007/IJARBSS/v11-i19/11740

DOI:10.6007/IJARBSS/v11-i19/11740

Received: 08 October 2021, Revised: 10 November 2021, Accepted: 29 November 2021

Published Online: 20 December 2021

In-Text Citation: (Wijekoon et al., 2021)

To Cite this Article: Wijekoon, R., Sabri, M. F., Ahmad, N., \& Rahim, H. A. (2021). Understanding the Path Toward Family Economic Well-Being of Coconut Growers. International Journal of Academic Research in Business and Social Sciences, 11(19), 327-348.

\section{Copyright: (c) 2021 The Author(s)}

Published by Human Resource Management Academic Research Society (www.hrmars.com) This article is published under the Creative Commons Attribution (CC BY 4.0) license. Anyone may reproduce, distribute, translate and create derivative works of this article (for both commercial and non-commercial purposes), subject to full attribution to the original publication and authors. The full terms of this license may be seen at: http://creativecommons.org/licences/by/4.0/legalcode 


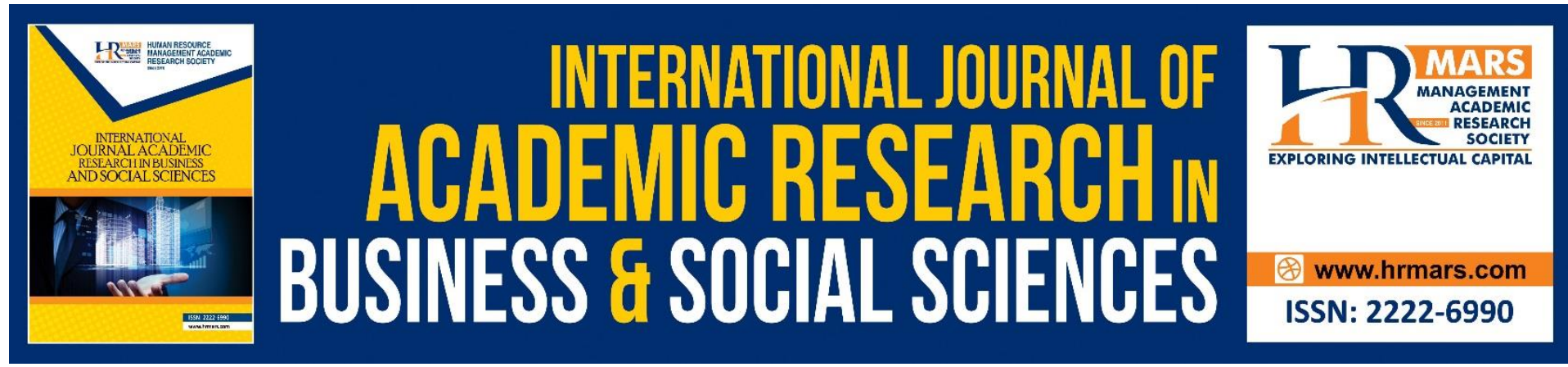

\title{
Understanding the Path Toward Family Economic Well-Being of Coconut Growers
}

\author{
Rusitha Wijekoon ${ }^{2,3}$, Mohamad Fazli Sabri ${ }^{1,2}$, Nobaya Ahmad ${ }^{1,4}$ \\ \& Husniyah Abdul Rahim ${ }^{2}$ \\ ${ }^{1}$ Institute for Social Science Studies (IPSAS), Universiti Putra Malaysia, 43400 UPM Serdang, \\ Selangor, Malaysia, ${ }^{2}$ Department of Resource Management \& Consumer Studies, Faculty of \\ Human Ecology, Universiti Putra Malaysia, 43400 UPM Serdang, Selangor, Malaysia, \\ ${ }^{3}$ Technology Transfer Division, Coconut Research Institute of Sri Lanka, Lunuwila, 61150, Sri \\ Lanka. ${ }^{4}$ Department of Social and Development Sciences, Faculty of Human Ecology, \\ Universiti Putra Malaysia, 43400 UPM Serdang, Selangor, Malaysia \\ Email: dean.eco@upm.edu.my, ipsas@upm.edu.my,fazli@upm.edu.my, \\ nobaya@upm.edu.my, husniyah@upm.edu.my.
}

\begin{abstract}
Many countries are establishing national programs to increase their citizens' family economic well-being. However, the concept of family economic well-being is still in its infancy, with only a few models established for developing countries. Thus, to create and implement effective policies, it is necessary to comprehend the concept family economic well-being from a multidisciplinary and multi-dimensional perspective, especially for a developing country like Sri Lanka. In the current study, path analysis was performed to examine the drivers that affect family economic well-being of coconut growers in Sri Lanka. Data from 400 respondents were analyzed empirically to validate the hypothesized relationships using the PLS-SEM approach. The findings provide support for the relationships between money attitude, technology adoption, financial behavior, financial knowledge, and family economic well-being which explained $91.2 \%$ of variance in family economic well-being. Understanding the paths that lead to better individual economic well-being has the potential to aid in successful policymaking, and curriculum design to assist individuals' efforts to achieve greater family economic wellbeing.
\end{abstract}

Keywords: Financial Knowledge, Financial Behavior, Money Attitudes, Technology Adoption, Sri Lanka.

\section{Introduction}

Family economic well-being is a multidimensional concept, and each dimension of economic well-being is itself an accumulation of several underlying trends, on which the prevailing literature is varies in quality as well as frequently fluctuates across country to country, community to community, and even within families (Osberg \& Sharpe, 2002). Hence, academics sometimes apply family economic well-being to describe the macroeconomic state of all families in the population or they utilize the concept to describe precise micro 
circumstances in a family (Bauer et al., 2012). In reality policy makers need to increase the steadiness of the families in the society, over their life span to fulfill most of their economical necessities by themselves (Bauer et al., 2012). Thus, it is vital to examine more broadly about the family economic well-being, and what determinants that affect the economy of a family. More comprehensive knowledge on the drivers of family economic well-being helps policy makers to overcome those obstacles to implement poverty alleviation programs in order to increase the level of household economic well-being (Wijekoon et al., 2021), and reduce their financial vulnerabilities because poverty is one of the crucial social problems in developing countries like Sri Lanka. Furthermore, poverty and economic well-being are interlinked, which would reflect each other (Ahmad \& Paim, 2012).

The coconut palm is one of the key plantation crops in Sri Lanka which is widely cultivated by the smallholders. Further, its contribution for livelihood, and economy of Sri Lanka is significant, because it offers direct, and indirect livelihood for around 700,000 people, and contributed Rs. 108.9 billion (US $\$ 609.77$ million) foreign exchange in 2019 which accounted $0.8 \%$ GDP (Central Bank of Sri Lanka, 2019). Thus, coconut cultivation is considered as one of the major income generating pathways, and included in poverty alleviation programs in Sri Lanka, because income is the most widely utilizing indicator for economic well-being (Xiao, 2013). But, due to low productivity of the coconut cultivations expected potential yield could not be achieved, and final result is less income. Moreover, inconsistent nature of farm gate price is another contributory factor that affects coconut growers' income (Herath \& Wijekoon, 2021), and the level of their family economic well-being also fluctuated accordingly. According to Sri Lanka Coconut Research Institute (CRISL), coconut growers have to follow the recommendations that are important to achieve the expected potential yield. Therefore, technology adoption plays an important role in increasing the income of the coconut growers as well as their family economic well-being (Ahmed et al., 2017). But, Wu et al. (2010) stated that examining the effect of technology adoption on growers' family economic well-being is challenging due to the complications of splitting the technology adoption impacts from other socioeconomic factors.

According to Ajzen and Fishbein (2000) behaviors lead to outcomes, and as predictable positive economic behaviors influence the family economic well-being. Economic behavior could be described as "any human behavior that generates, and manages economic resources to improve economic well-being" (Xiao, 2013, p. 582), and further explained that earning, budgeting, spending, borrowing, and saving as common economic behaviors. Except for earning, the other behaviors are referred as financial behaviors. Moreover, financial literacy associated factors, for example, financial knowledge and money attitudes also play a significant role in increasing the economic well-being of the people (Xiao, 2013).

Even though, some past studies distinguished some drivers of family economic well-being, and also hinted at potential explanations behind being or reaching to a higher level of family economic well-being, possible determinants of family economic well-being are still not explained the phenomenon completely (OECD, 2013). Further, while policymakers point out the significance of investigating individual's tendency to drift toward higher economic wellbeing, recently academicians have focused more to reveal the gaps of the determinants of family economic well-being. According to the OECD (2011), assessing family economic wellbeing needs a comprehensive framework that comprises a large number of constituents, and 
preferably, permits assessing how their interrelationships shape individual's lives because economic well-being is a multifaceted phenomenon with several of its determinants intensely linked with one another. Hence, this study addresses this gap, and according to the best of knowledge of the authors this is the first time that examine the effect of agricultural technology adoption on family economic well-being by combining with financial related elements, for instance financial knowledge, financial behavior, and money attitudes.

\section{Literature Review}

\section{Family Economic Well-Being}

Although the concept of family economic well-being is extensively referred, it does not have generally established definition of just what it is, and the terms quality of life, well-being, happiness, and life satisfaction are frequently applied interchangeably (OECD, 2013). But, Xiao (2013) defined family economic well-being as "a family economic status that has sustainably adequate economic resources to live a comfortable life" (Xiao, 2013, p. 573). It is one of the major components of the well-being which govern individual's consumption likelihoods, and their command over resources (OECD, 2013). Moreover, OECD (2011) claims that income, and wealth are vital constituents of family economic well-being. People's income allows them to meet their basic necessities, and pursue a variety of additional goals that are important to them, while their wealth allows them to maintain these choices over time. As a result, practically all institutions that produce well-being measures recognize the value of family economic well-being to overall well-being, but the relationship between family economic well-being, and overall well-being is not necessarily straightforward (OECD, 2013).

\section{Financial Knowledge}

Financial knowledge is "the ability to understand financial concepts, and positively related to financial practices such as, cash flow management, credit management, savings, and investment" (Robb \& Woodyard, 2011, p. 65). With the enhanced financial knowledge individuals can understand financial concepts better, and make wise decisions to improve their economic well-being. Moreover, according to Kholilah and Iramani (2013), seven areas to be fulfilled to have a good financial knowledge such as, "1) knowledge of interest, and credit, 2) knowledge related to financial budget preparation, 3) knowledge of investment in deposits, 4) knowledge of investment shares, 5) knowledge of how to invest in property, 6) knowledge of investing in mutual funds, and 7) knowledge of insurance" (p. 70). Delafrooz and Paim (2011), and Joo and Grable (2004) have confirmed that financial knowledge has a positive correlation with financial well-being. Moreover, Falahati et al (2012), and Sabri and Falahati (2013) also proved the relationship later. Therefore, a positive correlation between financial knowledge, and family economic well-being were revealed, and below hypothesis could be developed.

$\mathrm{H}_{1}$ : Financial knowledge is positively linked with the family economic well-being of Sri Lankan coconut growers.

\section{Financial Behavior}

Financial behavior is "the acquisition, allocation, and use of financial resources oriented toward some goal" (Topa et al., 2018, p. 3). A person's financial behavior could be examined by investigating how efficient he/she handles cash, savings, debt, and other expenses (Hasibuan et al., 2018). According to Atkinson and Messy (2012), healthy financial behavior, 
such as proper budgeting, and financial stability, improves individual's well-being, but poor financial behavior, such as heavily depending on credit, and loans, declines the well-being. But, Fei et al (2020); and Sabri et al (2020a) observed a negative association between financial behavior, and financial vulnerability which is negatively affected family economic well-being. Empirical evidence suggests that when households master on proper financial management, both of their economic well-being, and financial satisfaction increase at the long term (Consumer Financial Protection Bureau, 2015). Moreover, positive financial behaviors, such as financial management, savings behavior, investment behavior are significant drivers of good financial well-being (Sabri et al., 2020b). However, financial management behavior is complex, and supervision of money, and expenditure, which includes frugal, and careful spending of money is a worthwhile security against risky financial behaviors (Topa et al., 2018). Because of these evidences, it is assumed that a positive association is existed between financial behavior, and family economic well-being.

$\mathrm{H}_{2}$ : Financial behavior is positively associated with the family economic well-being of Sri Lankan coconut growers.

\section{Money Attitudes}

Money attitude can be described as "personal inclination towards financial matters" (Rai et al., 2019, p. 54). As well as it is an individual's capability to plan ahead, and maintain a savings account that matters. According to Ajzen (1991), financial attitudes are outcome of a certain behavior of a decision-maker, and the attitude could be embedded through their economic, and non-economic beliefs. Financial attitudes along with financial behavior can also affect financial well-being as well as economic well-being (Rai et al., 2019). According to the literature study, financial attitude is a necessary component for determining financial literacy in individuals, and it also determines financial literacy levels. Sabri et al. (2020c) concluded that money attitude is a significant determinant of Malaysian employees' financial well-being. Meanwhile, Poh et al. (2021) reported a negative correlation between money attitudes, and financial vulnerability. Moreover, individual's money attitudes would affect their behaviors when they are shopping, and saving, and lastly is heading off with an impact on achievement of certain life goals (Nga \& Yeoh, 2015), and with productive life goals people gain higher level of economic well-being. Therefore, following hypothesis have been framed, and evaluated to state the relationship of money attitude and family economic well-being.

$\mathrm{H}_{3}$ : Money attitude is positively linked with the family economic well-being of Sri Lankan coconut growers.

\section{Technology Adoption}

Technology adoption is "the choice to acquire, and use a new innovation by an individual or an organization" (Wikipedia, 2021). Innovative technologies are expected to play a major role in the forming of sustainable agricultural systems in many circumstances (Diagne \& Cabral, 2017). According to previous studies on technology adoption in developing nations, the key obstacles hindering the adoption of sustainable technologies are lack of access to reliable information, and financial services (Alwang et al., 2019; Bernard et al., 2017). Householdspecific characteristics, for example, farmers education, gender, age, and household size are also play a vital role in the adoption process of technologies as well as rate of adoption (Theis et al., 2018). Wu et al. (2010) found a positive influence of technology adoption on rural 
growers' economic well-being in China. Moreover, findings of Ntshangase et al. (2018) revealed that growers' new technology adoption was positively correlated with higher maize yields as well as their economic well-being. Hence, based on the previous evidence of association between agricultural technology adoption, and family economic well-being, the formulated hypothesis is;

$\mathrm{H}_{4}$ : Agricultural technology adoption is positively associated with the family economic wellbeing of Sri Lankan coconut growers.

Grounded on the above discussed literature, and the hypotheses the developed research framework for the current study is;

Figure 1: Research framework

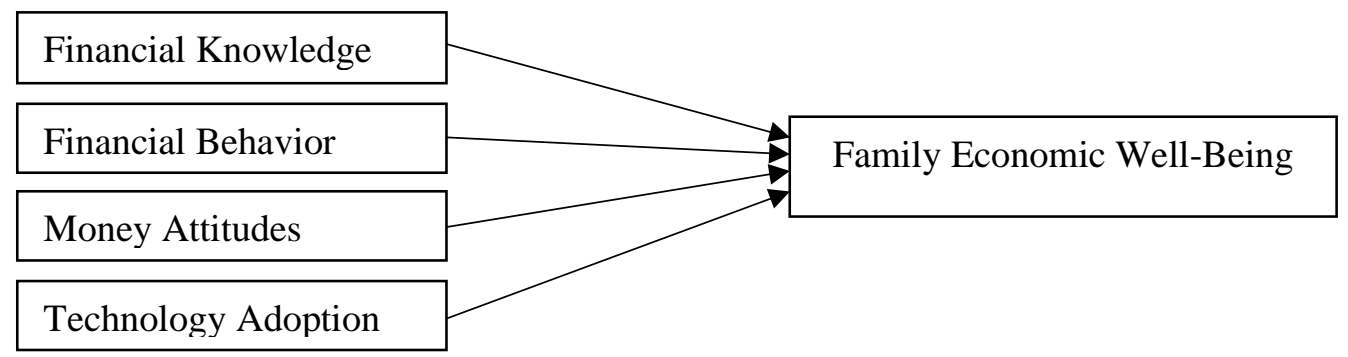

\section{Research Methodology}

Participants and Design

In the current study, a total of 416 respondents were chosen from the Coconut Triangle which is consisted of four regional areas (Gampaha, Kurunegala, Kuliyapitiya, Marawila) in Sri Lanka using multi-stage random sampling method, and 104 respondents were targeted from each region. A validity, and reliability of the questionnaire was tested with a pre-test of 40 randomly selected participants from the selected areas. Normality test was done for the collected data, and the results are given in the Table 1.

Table 1: Normality results

\begin{tabular}{lcc}
\hline \multicolumn{1}{c}{ Dimensions } & Skewness & Kurtosis \\
\hline Financial Knowledge & 0.710 & -0.587 \\
Financial Behavior & 0.348 & -1.044 \\
Money Attitudes & -0.134 & -1.474 \\
Technology Adoption & -0.182 & -1.631 \\
Economic Well-Being & -0.074 & -1.675 \\
\hline
\end{tabular}

Normality was tested with skewness, and kurtosis, and if, both parameters are within the range of -2 and +2 , the data set was considered normally distributed (George \& Mallery, 2003). All the values were within the given range, and normal distribution was assumed.

Measurements have been validated for content, and construct validities apart from the reliability test (Table 2 ). 
Table 2: Reliability and validity results

\begin{tabular}{lcc}
\hline \multicolumn{1}{c}{ Dimensions } & $\begin{array}{c}\text { Construct } \\
\text { Reliability }\end{array}$ & $\begin{array}{c}\text { Average } \\
\text { Variance } \\
\text { Extracted }\end{array}$ \\
\hline Financial Knowledge & 0.841 & 0.423 \\
Financial Behavior & 0.845 & 0.414 \\
Money Attitudes & 0.890 & 0.604 \\
Technology Adoption & 0.964 & 0.888 \\
Economic Well-Being & 0.960 & 0.455 \\
\hline
\end{tabular}

The convergent validity was tested using Average Variance Extracted (AVE), and according to Fraering and Minor (2006), if the AVE value for a construct is 0.4 or above, validity was confirmed. AVE values for all five constructs were above 0.4 , and validity of the constructs was achieved. The measurement items are considered reliable when the Cronbach's alpha value equals or exceeds 0.6 (Hair et al., 2006). All the Cronbach's alpha values recorded were above 0.8 , and constructs were reliable.

Multicollinearity test was done to identify whether one or more variables are highly correlated with each other. Multicollinearity occurs when the variance inflation factor (VIF) value is higher than five (Hair et al., 2014). The multicollinearity results of the variables are given in the Table 3.

Table 3: Multicollinearity test results

\begin{tabular}{lc}
\hline \multicolumn{1}{c}{ Model Variables } & $\begin{array}{c}\text { Collinearity } \\
\text { Statistics }\end{array}$ \\
\cline { 2 - 2 } & VIF \\
\hline Financial Knowledge & 1.507 \\
Financial Behavior & 2.520 \\
Money Attitudes & 3.585 \\
Technology Adoption & 2.768 \\
Economic Well-Being & 2.653 \\
\hline
\end{tabular}

The VIF values show that there was no multicollinearity between the constructs as the VIF values are below five, which are within the acceptable range (Hair et al., 2014). This has shown that there was low redundancy among the constructs. As a result of final survey 400 duly completed questionnaires were received, and subjected to the data analysis. Descriptive analysis, and path coefficient statistics were performed with SPSS version 26 , and PLS-SEM 3.3 , respectively.

\section{Instruments}

Financial knowledge was assessed with the 16 "Yes or No" items which were adapted from Hogarth and Hilgert (2002), and the questionnaire covered three financial knowledge topics; credit, savings, and general financial knowledge. Financial behavior items were adapted from Sabri et al. (2012) that was consisted of 12 items of five point Likert scale which was ranged never (1) to very frequent (5). Cash management, credit management, retirement planning, real estate planning, and risk management areas of financial behavior were covered. 
Ten items were adapted from the money attitude scale which was introduced by Furnham (1984) ranging from strongly disagree (1) to strongly agree (5). Finally, technology adoption was examined using five Likert scale questions ranging strongly disagree (1) to strongly agree (5) which were adapted from Abdekhoda et al. (2015), and Shareef et al. (2011). Economic well-being questionnaire was comprised of 34 items which were adopted, and adapted from Bigot et al., 2017; Diener et al., 1985; Haver et al., 2015; Kinderman et al., 2011; Orsila et al., 2011; and Radzyk, 2014. It was evaluated on a 5-Likert scale ranging from completely dissatisfied (1) to completely satisfied (5) which covered all the key aspects of the economic well-being; physical, social, emotional, intellectual, vocational, environmental, spiritual, and financial.

\section{Results and Discussion}

Demographic Profile of the Respondents

The demographics of the respondents are summarized in the Table 4.

Table 4: Demographics of the respondents

\begin{tabular}{|c|c|c|}
\hline Respondent's Background & Frequency & Percentage (\%) \\
\hline \multicolumn{3}{|l|}{ Gender } \\
\hline Male & 294 & 73.5 \\
\hline Female & 106 & 26.5 \\
\hline \multicolumn{3}{|l|}{ Ethnicity } \\
\hline Sinhala & 370 & 92.5 \\
\hline Tamil & 13 & 3.3 \\
\hline Muslim & 17 & 4.2 \\
\hline \multicolumn{3}{|l|}{ Religion } \\
\hline Buddhist & 295 & 73.7 \\
\hline Catholic & 75 & 18.7 \\
\hline Hinduism & 13 & 3.3 \\
\hline Islam & 17 & 4.3 \\
\hline \multicolumn{3}{|l|}{ Age (years old) } \\
\hline 40 and below & 53 & 13.3 \\
\hline $41-49$ & 92 & 23.0 \\
\hline $50-59$ & 94 & 23.5 \\
\hline $60-69$ & 104 & 26.0 \\
\hline $70-79$ & 57 & 14.2 \\
\hline Mean & 55.1 & \\
\hline \multicolumn{3}{|l|}{ Education Level } \\
\hline Primary & 13 & 3.3 \\
\hline GCE/OL & 30 & 7.5 \\
\hline $\mathrm{GCE} / \mathrm{AL}$ & 230 & 57.5 \\
\hline Diploma & 37 & 9.3 \\
\hline $\mathrm{BSC}$ & 76 & 19.0 \\
\hline MSc/ M. Phill/ PhD & 14 & 3.5 \\
\hline \multicolumn{3}{|l|}{ Marital Status } \\
\hline Unmarried & 9 & 2.3 \\
\hline Married & 342 & 85.5 \\
\hline Divorced & 10 & 2.5 \\
\hline
\end{tabular}


Widowed

\section{No. of dependents}

1

$2-3$

4-5

More than 5

Mean

Income groups

$\leq$ SLR 30,000

SLR 30,001 - SLR 50,000

LR 50,001 - SLR 75,000

SLR 75,001 - SLR 100,000

SLR $\geq$ SLR 100,001
39

1

20

259

120

4.94
9.7

0.3

5.0

64.8

30.0

Financial Knowledge

Higher percentage score of the financial knowledge statement shows respondent's high financial knowledge for the particular area in credit, savings, and general financial knowledge, whereas lower percentage score shows their less financial knowledge (Table 5).

Table 5: Respondents' financial knowledge

\begin{tabular}{clc}
\hline No. & \multicolumn{1}{c}{ Statement } & $\begin{array}{c}\text { Respondents } \\
\text { who }\end{array}$ \\
\hline 1 & $\begin{array}{l}\text { Credit card holders can spend without limit. } \\
2\end{array}$ & $\begin{array}{l}\text { Making payments late on your credit card bills can make it more difficult } \\
\text { to take out a loan. }\end{array}$ \\
& With compound interest, you earn interest on your interest, as well as & 98.0 \\
3 & on your principal. & 99.7 \\
4 & If you have a savings account at a bank, you may have to pay taxes on & 56.8 \\
5 & All types of investments are profitable and low risk. & 96.5 \\
6 & All investments in Sri Lanka are legal. & 92.2 \\
7 & Individuals need to save a minimum 10\% for emergency purposes. \\
8 & You should have an emergency fund that covers two to six months of & 100.0 \\
9 & The longer the repayment period, the lower the cost of the overall loan. & 99.2 \\
10 & Debt cannot be inherited. & 74.8 \\
11 & If I could bear the risk, I don't have to buy insurance. & 93.8 \\
12 & All types of risk can be insured. & 60.0 \\
13 & Sometimes, expenses can be higher than income. & 85.2 \\
14 & Shopping lists help to control expenses. & 64.3 \\
15 & Only I have assets, I will write a Will. & 98.2 \\
16 & Wills cannot be modified once it's written. & 99.2 \\
\hline
\end{tabular}


The items "credit card holders can spend without limit", and "individuals need to save a minimum $10 \%$ for emergency purposes" are the statement that answered correctly by most of the respondents (100\%), suggesting that majority of respondents understand about credit cards' spending limit as well as they knew the importance of the saving money for a future emergency. On the contrary, it was astonished to find that many respondents (56.8\%) failed to answer correctly on the statement "if you have a savings account at a bank, you may have to pay taxes on the interest you earn", indicated that the information behind the taxation process on savings was still a major problem faced by the respondents. Furthermore, the statements "if I could bear the risk, I don't have to buy insurance", and "sometimes, expenses can be higher than income" are also received lower percentage of score means a poor knowledge of the growers on insurance procedures, and the link between income and expenses, respectively.

\section{Financial Behavior}

The mean scores of the financial behavior statements are given in the Table 6. Higher mean score shows respondent's positive financial behavior for the given areas; cash management, credit management, retirement planning, real estate planning, and risk management whereas lower mean score shows their less positive or more nagative financial behavior.

Table 6: Respondents' financial behavior

\begin{tabular}{lrr}
\hline No. Statement & Mean & $\begin{array}{c}\text { Standard } \\
\text { Deviation }\end{array}$ \\
\hline
\end{tabular}

\section{Cash Management}

1 I spend accordingly to a weekly or monthly budget.

$2.16 \quad 1.38$

2 I record how and where my money is spent.

$2.82 \quad 1.23$

3 I always set aside money for unexpected expenses in the

$3.47 \quad 1.42$

4 I contribute money to retirement accounts.

$3.09 \quad 1.99$

\section{Credit Management}

5 I usually do not pay in full the loan balance, but only make a 4.75 minimum or partial payment.

6 I took a cash advance from credit card to pay off my loan

\section{Retirement Planning}

7 I contribute to private retirement savings plan.

8 I discuss retirement plans with spouse, friend or others.

$2.07 \quad 1.41$

\section{Real Estate Planning}

9 I have the will for distribution of property in the event of death.

\section{Risk Management}

$\begin{array}{llll}11 & \text { I ensure an adequate income in case of disability. } & 4.59 & 0.74\end{array}$

12 I provide financial security to the dependents in case of death. $\quad \begin{array}{ll}3.10 & 1.67\end{array}$

It has been identified that the most performed cash management behavior was keeping money aside for future unexpected issues (Mean= 3.47), and the least carried out cash management behavior was following a budget for the weekly or monthly expenses (Mean= 
2.16). Based on the results, the coconut growers gave priority to save money for future than budgeting. But, Mien and Said (2018) revealed that unfavorable consumption is the result of non-appropriate budgeting. Moreover, majority of the growers used to pay minimum payment for their loans, and rarely take cash advances from credit cards which leads to high financial well-being levels (Sabri et al., 2020c). Even though, lack of retirement planning leads people less optimistic, and less confident with their retirement life (Sabri et al., 2015), most of the growers did not contribute to a private retirement savings plan, and rarely discuss about the retirement plans with others. In line with Rajna and Sabri (2015), least performed financial behavioral domain for the growers was real estate planning. But, they perform well in risk management behaviors.

\section{Money Attitude}

The higher mean score reflects greater money attitude (except reverse coded items) (Table 7). Respondents showed unnecessary money attitude aspects, for example, "I would often buy something that wasn't necessary just to attract the others" but, unwise spending is one of the major cause of financial vulnerability (Aw et al., 2018). Savings related money attitudes, for instance, "I am proud of my ability to save", and "I prefer to save because I am not sure what will happen in the future" had above average mean scores, and indicated that average attitudes towards the money. Sabri et al. (2020c) found that savings related positive money attitudes play an important role to achieve higher financial well-being levels in Malaysian employees. Moreover, coconut growers' satisfaction about their financial achievements was found just over an average (Mean=3.0).

Table 7: Respondents' money attitude

\begin{tabular}{|c|c|c|c|}
\hline No. & Statement & Mean & $\begin{array}{l}\text { Standard } \\
\text { Deviation }\end{array}$ \\
\hline 1 & I believe money can solve all my problems. & 1.28 & 0.60 \\
\hline 2 & $\begin{array}{l}\text { I am proud of my financial achievements and want my friends } \\
\text { to know about them. }\end{array}$ & 3.19 & 1.48 \\
\hline 3 & $\begin{array}{l}\text { Although I have enough money, I often feel guilty when I spend } \\
\text { it for necessities.* }\end{array}$ & 4.26 & 0.94 \\
\hline 4 & I often get anxious when asked about my personal finances.* & 4.05 & 1.19 \\
\hline 5 & I am proud of my ability to save. & 3.16 & 1.58 \\
\hline 6 & I will allocate money for the fun things. & 2.33 & 1.33 \\
\hline 7 & $\begin{array}{l}\text { I would often buy something that wasn't necessary just to } \\
\text { attract the others.* }\end{array}$ & 4.51 & 0.85 \\
\hline 8 & $\begin{array}{l}\text { I prefer to save because I am not sure what will happen in the } \\
\text { future. }\end{array}$ & 3.52 & 1.53 \\
\hline 9 & I will always pay the utility bill immediately. & 3.83 & 1.21 \\
\hline 10 & I prefer to use cash instead of credit. & 4.49 & 0.80 \\
\hline
\end{tabular}

\section{Technology Adoption}

Table 8 displays the mean scores of the statements of technology adoption, and higher mean score indicates the higher degree adoption of the given dimension of the technology while lower mean score demonstrates growers' less towards the adoption. The construct was measured with five items which represents major four areas of coconut technologies; planting seedlings, pest and disease control, application of fertilizer, and moisture conservation. 
Table 8: Respondents' technology adoption

\begin{tabular}{llcc}
\hline No. & \multicolumn{1}{c}{ Statement } & Mean & $\begin{array}{c}\text { Standard } \\
\text { Deviation }\end{array}$ \\
\hline $1 \quad \begin{array}{l}\text { To plant seedlings, I use CRISL recommended technologies in } \\
\text { my coconut cultivation. }\end{array}$ & 3.25 & 1.71 \\
$\begin{array}{l}\text { To control pest and diseases, I use CRISL recommended } \\
\text { technologies in my coconut cultivation. }\end{array}$ & 3.68 & 1.40 \\
$\quad \begin{array}{l}\text { To apply fertilizers, I use CRISL recommended technologies in } \\
\text { my coconut cultivation. }\end{array}$ & 3.54 & 1.49 \\
$\quad \begin{array}{l}\text { To maintain moisture, I use CRISL recommended technologies } \\
\text { in my coconut cultivation. }\end{array}$ & 2.79 & 1.78 \\
$\quad \begin{array}{l}\text { I recommend my friends/relatives to use CRISL recommended } \\
\text { technologies in their coconut cultivation. }\end{array}$ & 4.26 & 0.94 \\
\hline $\begin{array}{l}\text { Note: CRISL-Coconut Research Institute of Sri Lanka } \\
\text { Based on the results, even though the coconut growers' technology adoption was very poor } \\
\text { (Mean was around 3), they like to recommend the technologies to other growers (Mean was } \\
\text { above 4). Moreover, most frequently adopted agricultural technologies were related to the } \\
\text { pest and disease control (Mean= 3.68), while moisture conservation practices (Mean= 2.79) }\end{array}$ \\
$\begin{array}{l}\text { were the least adopted technologies by the Sri Lankan coconut growers. Further, the results } \\
\text { are consistent with the findings of Legrand et al. (2018) in a previous study in Sri Lanka. }\end{array}$
\end{tabular}

Family Economic Well-Being

Due to the multidimensional nature of the family economic well-being, the construct was prepared to represent all the dimensions; physical, social, emotional, intellectual, vocational, environmental, spiritual, financial, and the received mean scores are presented in the Table 9. 
Table 9: Respondents' family economic well-being

\begin{tabular}{lcc}
\hline No. Statement & Mean & $\begin{array}{l}\text { Standard } \\
\text { Deviation }\end{array}$ \\
\hline
\end{tabular}

\section{Physical}

$1 \quad$ Are you satisfied with your physical health?

$3.86 \quad 0.77$

2 On the whole, are you satisfied with your physical capacities?

$4.39 \quad 0.70$

3 I am engaged and interested in my daily activities.

$4.41 \quad 0.70$

$4 \quad$ I am competent and capable in the activities that are important to me.

$4.65 \quad 0.61$

\section{Social}

5 Are you satisfied with your friendships and personal relationships?

$4.51 \quad 0.68$

"I enjoy meeting people for socializing". Are you satisfied with these statement?

$4.40 \quad 0.81$

7 "I am engaged in group activities". Are you satisfied with these

$3.69 \quad 1.03$

$8 \quad$ I live in a sociable neighborhood with cohesiveness.

$4.74 \quad 0.50$

9 My social relationships are supportive and rewarding.

$4.79 \quad 0.49$

\section{Emotional}

10 Are you satisfied with your dealing ability with problems?

$3.17 \quad 0.90$

11 "A lot of things about me are good", Are you satisfied with these statement?

$3.39 \quad 1.04$

12 How satisfied you are about your life?

$3.25 \quad 1.02$

13 "Whatever happens, I am able to adjust myself". Are you

13 satisfied with these statement?

$2.51 \quad 0.98$

\section{Intellectual}

14 I am engaged and interested in reading new knowledge. On the whole, are you satisfied with the ability of your innovations?

On the whole, are you satisfied with the ability of your

\section{Vocational}

18 Are you happy with your ability to work?

19 Time and money could be saved if work were better organized

19 in my coconut cultivation.

$4.63 \quad 0.54$

20 I have always wanted to perform to the best of my ability.

$3.50 \quad 1.19$

21 I am enthusiastic about my work with coconut cultivation.

$3.33 \quad 1.58$

\section{Environmental}

22 I would describe my satisfaction with where I live.

23 "I always engage in environmental friendly activities". Are you satisfied with these statement?

24 On the whole, are you satisfied with your relationship with the environment? 
26 I have been able to make up my mind about things.

$3.55 \quad 0.80$

27 I have been feeling optimistic about the future.

$2.43 \quad 1.00$

28 I have been feeling relaxed.

$3.39 \quad 1.20$

29 I am satisfied with my religious or spiritual life.

\section{Financial}

30 "I could handle a major unexpected expense". What is your response about this statement when it is applied to you?

$4.63 \quad 0.56$

31 "I am securing my financial future". What is your response about this statement when it is applied to you?

32 "I can enjoy life because of the way I'm managing my money". What is your response about this statement when it is applied to you?

33 "I have money left over at the end of the month". What is your response about this statement when it is applied to you?

34 "Giving a gift for a wedding, birthday or other occasion would put a strain on my finances for the month". What is your response about this statement when it is applied to you?*

In the physical aspect, high stability with their daily activities, and physical capacities were exhibited by the coconut growers with the mean values of 4.65 , and 4.39 respectively. But, physical health satisfaction was detected just over an average, and it was mainly due to the non-communicable diseases, for instance, arthritis, high blood pressure, diabetes, etc. prevailing among people, especially in older adults (Lago et al., 2018).

Concerning in social aspect, higher frequencies were shown for social relationships (Mean > 4.0). With the emotional aspect, lowest mean value (2.51) was recorded for the item, "whatever happens, I am able to adjust myself". Moreover, most of them were moderately satisfied when dealing with problems (Mean=3.17), and their satisfaction with the current life (Mean=3.25), which is indicating that most of the Sri Lankan coconut growers' emotional wellbeing was in moderate level.

With regards to intellectual aspect, respondents seemed to have less engaged in innovations (Mean=1.56), and inventions (Mean=1.50). But, less implementation of technological inventions and innovations in agriculture leads to decrease the productivity of the agricultural lands (Kumaraswamy \& Shetty, 2016). Even though, coconut growers were interested in reading new knowledge frequently (Mean=4.10), their engagement of new technologies were comparatively less (Mean=2.47). Herath and Wijekoon $(2013 ; 2021)$ also confirmed the fact in their study with Sri Lankan coconut growers.

In the aspect of vocational well-being, coconut growers strongly believed that they could save both time and money when organizing the agronomic practices in their coconut cultivation properly (Mean=4.63). Liliane and Charles (2020) also found that the unorganized agronomic practices in agricultural lands lead to a significant yield loss. But, most of the coconut growers were happy with their ability to work (Mean=3.89), and gained enthusiasm with the work related to the coconut cultivation (Mean=3.33). The environmental aspect was gained high 
responses, and all the items were above average. Nowadays, Sri Lankan government encourage the growers to implement environmental friendly agronomic practices, and growers' eco-friendly behaviors might be due to the effect of those policy implications. In the aspect of spiritual well-being, most of the growers were satisfied with their religious or spiritual life (Mean=4.63).

The results of financial aspect showed that just over average population of the coconut growers had money left over at the end of the month (Mean=3.63), and they enjoyed life because of the way of managing their money (Mean=3.46). These are considered as positive credit practices, and are important in individual's financial well-being (Rajana \& Sabri, 2015).

\section{Hypotheses Testing}

The path coefficient analysis through PLS-SEM was applied to study the relations between the determinants of family economic well-being, and family economic well-being. The model shown in the Figure 2 illustrates the PLS-SEM algorithm for path analysis. 
Figure 2: PLS Algorithm for the Determinants of Family Economic well-being

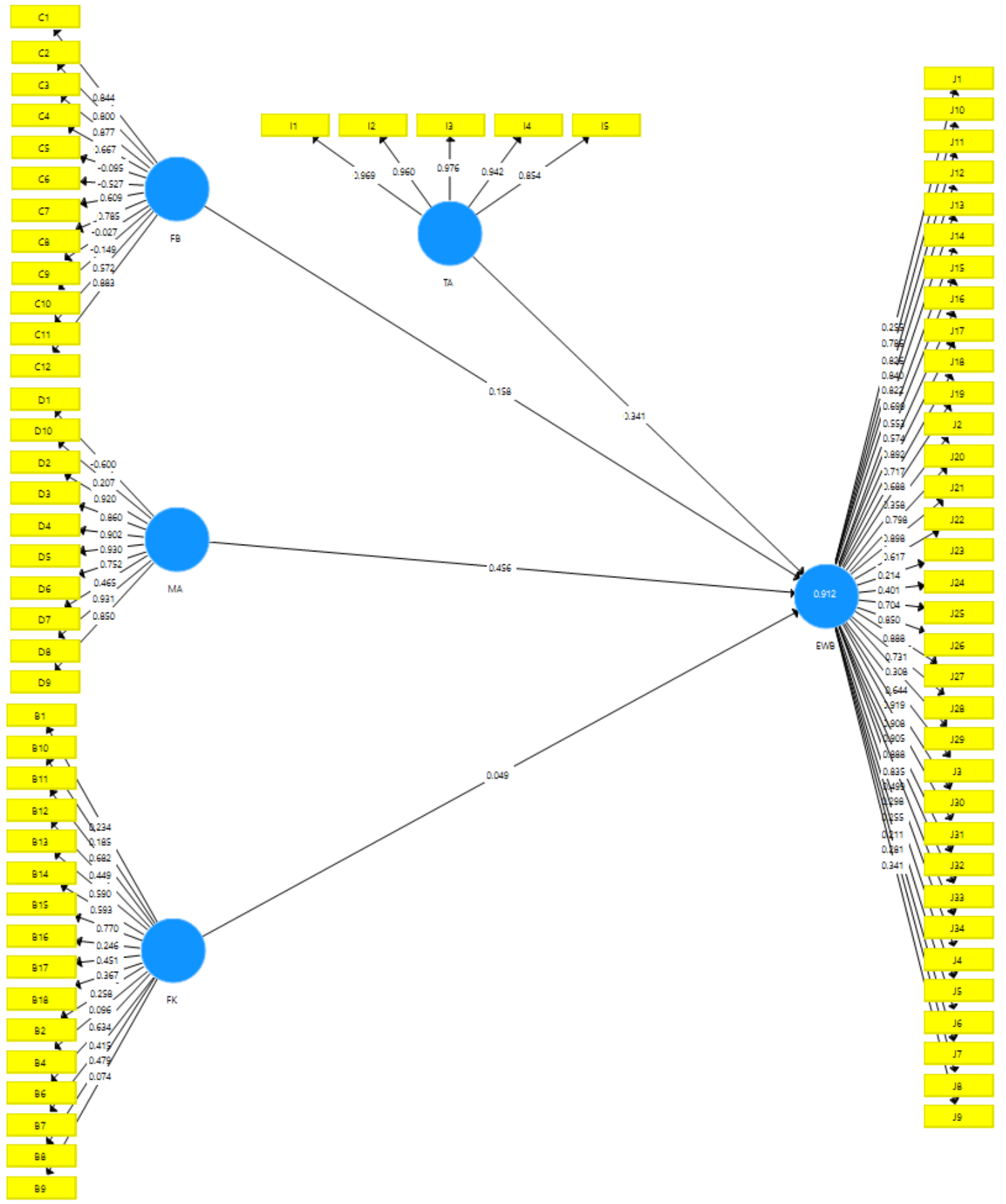

Based on the structural model, family economic well-being was strongly influenced by the growers' money attitudes $(\beta=0.456)$, followed by technology adoption $(\beta=0.341)$, financial behavior $(\beta=0.158)$, financial knowledge $(\beta=0.049)$, and $91.2 \%$ of the family economic wellbeing variance was explained by the selected determinants (Table 10). 
Table 10: Path coefficients

\begin{tabular}{|c|c|c|c|c|c|}
\hline Hypothesis & Relationship & Std. Beta & Std. Error & t-value & Result \\
\hline $\mathrm{H}_{1}$ & $\begin{array}{l}\text { Financial Knowledge - } \\
>\text { FEWB }\end{array}$ & 0.049 & 0.024 & 2.080 & Supported* \\
\hline $\mathrm{H}_{2}$ & $\begin{array}{l}\text { Financial Behavior -> } \\
\text { FEWB }\end{array}$ & 0.158 & 0.034 & 4.670 & Supported ** \\
\hline $\mathrm{H}_{3}$ & Money Attitudes -> FEWB & 0.456 & 0.039 & 11.777 & Supported ** \\
\hline $\mathrm{H}_{4}$ & $\begin{array}{l}\text { Technology Adoption -> } \\
\text { FEWB }\end{array}$ & 0.341 & 0.031 & 11.007 & Supported $* *$ \\
\hline
\end{tabular}

All four explanatory variables; financial knowledge, financial behavior, money attitudes, and technology adoption were significant, hence, the hypotheses $H_{1}, H_{2}, H_{3}$, and $H_{4}$ were accepted. Further, all four determinants; financial knowledge, financial behavior, money attitudes, and technology adoption were positively predicted the family economic well-being, and the growers with greater financial knowledge, financial behavior, money attitudes, and technology adoption have shown a high of family economic well-being.

In general, better financial decisions were taken by the individuals who are having a greater financial knowledge (Atkinson \& Messy, 2012). Lee et al (2020) revealed a positive association between financial knowledge, and individual well-being. Moreover, a positive influence of financial knowledge on women's well-being was detected by Zulfiqar and Bilal (2016). Therefore, the positive association between growers' financial knowledge, and family economic well-being can be accepted.

Based on the results of Chavali et al (2021), except for credit commitment all the other four financial behavioral factors; savings, and investments, future security, financial consciousness, and credit indiscipline have an influence on the financial well-being of people in India. In another study Chikezie and Sabri (2017) showed a significant correlation between financial well-being and financial behavior among university students in Malaysia. Moreover, financial behavior is accompanied with financial well-being directly and indirectly via objective financial situation (Sehrawat et al., 2021). The financial well-being is one of the major dimensions of the family economic well-being, and hence, the positive significant result between financial behavior and family economic well-being is acceptable.

The result inferred that growers with high money attitudes have higher family economic wellbeing levels, and the result is in line with numerous prior studies (Abdullah et al., 2019; Sabri \& Zakaria, 2015). Further, the attitude towards money varies from individual to individual (Rimple \& Taneja, 2012), and money attitudes are the major contributory factor to Sri Lankan coconut growers' economic well- being. Therefore, varying family economic well-being among Sri Lankan coconut growers could be explained. Moreover, the linkage between money attitude, and economic well-being in the present study was further confirmed by several prior studies.

The positive relationship revealed in the current study between technology adoption, and family economic well-being is consistent with Wu et al's (2010) study, which found a significant effect of improved rice technology adoption on Chinese paddy growers' well-being. 
Moreover, increasing well-being among the growers who adopt hybrid seed technologies was observed by (Smale and Mason, 2014). Therefore, the linkage between technology adoption, and family economic well-being in current study was further validated by several prior studies.

\section{Conclusions}

All four evaluated hypotheses as suggested in the study framework, are empirically supported. Hence, the current study provides empirical evidence that the financial knowledge, financial behavior, money attitudes, and technology adoption have a significant effect on the family economic well-being of Sri Lankan coconut growers. Further, $91.2 \%$ of the variance of family economic well-being was also explained by the model. Among all the determinants directly linked with family economic well-being in the proposed model, money attitude $(\beta=0.456, t=11.777, p<0.001)$ has the greatest influence trailed by technology adoption ( $\beta=0.341, t=11.007, p<0.001)$, financial behavior $(\beta=0.158, t=4.670, p<0.001)$, and financial knowledge $(\beta=0.049, t=2.080, p<0.05)$.

Current study contributes to the scientific literature by means of theoretically, and practically in the context of family economic well-being. Though, further improvements are remained. This study is based on coconut growers in the Coconut Triangle in Sri Lanka, and further research can be conducted to represent other agricultural populations. Moreover, even though Sri Lankan coconut cultivation is dominated by old growers, a novel trend could be seen in young adults to enter the industry, and it would be a very good sign to the policy makers to implement programs to attract more youth to the coconut cultivation to enhance their family economic well-being. In this process efficient technology transferring methods could be more effective to transfer the new technologies to the grass root level. Further, as suggested by Sabri et al (2019), gamification and edutainment incorporated tools such as, Smart Money Kits could be a good solution to enhance the financial knowledge, money attitudes, and financial behavior of children to make financially prudent adults in future. Moreover, male growers to female growers' ratio in coconut cultivation in Sri Lanka is 3:1, and hence conducting gender specific awareness programs (Sabri \& Wijekoon, 2019) to improve their financial related factors is another specific area that would be considered by the Ministry of Plantation Industries in order to enhance Sri Lankan coconut grower' family economic well-being.

\section{Acknowledgments}

The authors acknowledge the financial assistance given by the Sri Lanka Council of Agricultural Research Policy (SLCARP Capacity Building Program 2018-2022), and Sri Lanka Coconut Research Institute for the resources given for the data collection.

\section{References}

Abdekhoda, M., Ahmadi, M., Gohari, M., \& Noruzi, A. (2015). The effects of organizational contextual factors on physicians' attitude toward adoption of Electronic Medical Records. Journal of Biomedical Informatics, 53, 174-179.

Abdullah, N., Sabri, M. F., \& Arif, A. M. M. (2019). The Relationship between attitude towards money, financial literacy and debt management with young worker's financial wellbeing. Pertanika Journal of Social Sciences and Humanities, 27(1), 361-387.

Ahmad, N. F., \& Paim, L. (2012). Income poverty status and well-being of the vulnerable 
households in Malaysia: A comparative study. In N. Sulaiman, N. Yahaya, M. A. Razak, N. A. A. N. A. Aziz, \& T. Suhaimi (Eds.), Prosiding Seminar (p. 171). Persatuan Ekonomi Pengguna Dan Keluarga Malaysia (MACFEA).

Ahmed, M. H., Geleta, K. M., Tazeze, A., \& Andualem, E. (2017). The impact of improved maize varieties on farm productivity and wellbeing: Evidence from the east hararghe zone of Ethiopia. Development Studies Research, 4(1), 9-21.

Ajzen, I. (1991). The theory of planned behavior. Organizational behavior and human decision processes, 50(2), 179-211.

Ajzen, I., \& Fishbein, M. (2000). Attitudes and the attitude-behavior relation: Reasoned and automatic processes. European Review of Social Psychology, 11(1), 1-33.

Alwang, J., Gotor, E., Thiele, G., Hareau, G., Jaleta, M., \& Chamberlin, J. (2019). Pathways from research on improved staple crop germplasm to poverty reduction for smallholder farmers. Agricultural Systems, 172, 16-27.

Central Bank of Sri Lanka. (2019). Annual Report 2019. Retrieved on 31/08/2021 from https://www.cbsl.gov.lk/en/publications/economic-and-financial-reports/annualreports/annual-report-2019

Atkinson, A., \& Messy, F. A. (2012). Measuring financial literacy: Results of the OECD. OECD working papers on finance, insurance and private pensions, 44(2), 296-316.

Aw, E. C.-X., Cheah, J.-H., Ng, S. I., \& Sambasivan, M. (2018). Breaking compulsive buyingfinancial trouble chain of young Malaysian consumers. Young Consumers, 19(3), 328344.

Bauer, M. A., Wilkie, J. E. B., Kim, J. K., \& Bodenhausen, G. V. (2012). Cuing consumerism: Situational materialism undermines personal and social well-being. Psychological Science, 23(5), 517-523.

Bernard, T., De Janvry, A., Mbaye, S., \& Sadoulet, E. (2017). Expected product market reforms and technology adoption by Senegalese onion producers. American Journal of Agricultural Economics, 99(4), 1096-1115.

Bigot, F., Castanon, E., Baldini, C., Hollebecque, A., Carmona, A., Postel-Vinay, S., Angevin, E., Armand, J.-P., Ribrag, V., Aspeslagh, S., \& others. (2017). Prospective validation of a prognostic score for patients in immunotherapy phase I trials: The Gustave Roussy Immune Score (GRIm-Score). European Journal of Cancer, 84, 212-218.

Consumer Financial Protection Bureau. (2015). Financial well-being: The goal of financial education. Retrieved on 31/08/2021 from https://www.consumerfinance.gov/ dataresearch/ research-reports/financial-well-being.

Chavali, K., Raj, P. M., \& Ahmed, R. (2021). Does financial behavior influence financial wellbeing? Journal of Asian Finance, Economics and Business, 8(2), 273-280.

Chikezie, O. C., \& Sabri, M. F. (2017). The financial well-being of Nigerian students in Universiti Putra Malaysia. Journal of Education and Social Sciences, 6(2), 287-294.

Delafrooz, N., \& Paim, L. H. (2011). Determinants of financial wellness among Malaysia workers. African Journal of Business Management, 5(24), 10092-10100.

Diagne, A., \& Cabral, F. J. (2017). Agricultural transformation in Senegal: Impacts of an integrated program. Partnership for Economic Policy Working Paper, 2017-09.

Diener, E. D., Emmons, R. A., Larsen, R. J., \& Griffin, S. (1985). The satisfaction with life scale. Journal of Personality Assessment, 49(1), 71-75.

Falahati, L., Sabri, M. F., \& Paim, L. H. J. (2012). Assessment a model of financial satisfaction predictors: Examining the mediate effect of financial behavior and financial strain. World Applied Sciences Journal, 20(2), 190-197. 
Fei, C., Sabri, M. F., Mohamed, N. A., Wijekoon, R., \& Majid, A. Z. A. (2020). Determinants of financial vulnerability. Journal of Critical Reviews, 7(15), 3097-3107.

Fraering, M., \& Minor, M. S. (2006). Sense of community: An exploratory study of US consumers of financial services. International Journal of Bank Marketing, 24(5), 284-306.

Furnham, A. (1984). Many sides of the coin: The psychology of money usage. Personality and Individual Differences, 5(5), 501-509.

George, D., \& Mallery, P. (2003). SPSS for Windows step by step: A simple guide and reference $\left(4^{\text {th }}\right.$ ed.). Allyn \& Bacon.

Hair, J. F., Black, W. C., Babin, B. J., Anderson, R. E., \& Tatham, R. L. (2006). Multivariate data analysis ( $6^{\text {th }}$ ed.). Pearson Education.

Hair, J. F. Jr., Hult, G. T. M., Ringle, C. M., Sarstedt, M. (2014). A Primer on partial least squares structural equation modeling (PLS-SEM). European Journal of Tourism Research, 6(2), 211-213.

Hasibuan, B. K., Lubis, Y. M., \& HR, W. A. (2018). Financial literacy and financial behavior as a measure of financial satisfaction. Retrieved on 30/08/2021 from https://doi.org/10.2991/ebic-17.2018.79.

Haver, A., Akerjordet, K., Caputi, P., Magee, C., \& Furunes, T. (2015). Measuring mental wellbeing: A validation of the Short Warwick-Edinburgh Mental Well-Being Scale in Norwegian and Swedish. Scandinavian Journal of Public Health, 43(7), 721-727.

Herath, C. S., \& Wijekoon, R. (2013). Study on attitudes and perceptions of organic and nonorganic coconut growers towards organic coconut farming. Idesia (Arica), 31(2), 5-14.

Herath, C. S., \& Wijekoon, R. (2021). Growers' fertilizer application behavior and their willingness to pay for the fertilizer: a study in coconut triangle of Sri Lanka. Thai Journal of Agricultural Science, 54(1), 1-17.

Hogarth, J. M., \& Hilgert, M. A. (2002). Financial knowledge, experience and learning preference: preliminary results from a survey on financial literacy. Journal of Family and Consumer Sciences, 48, 1-7.

Joo, S., \& Grable, J. E. (2004). An exploratory framework of the determinants of financial satisfaction. Journal of Family and Economic Issues, 25(1), 25-50.

Kholilah, N. Al, \& Iramani, R. (2013). Studi financial management behavior pada masyarakat Surabaya. Journal of Business and Banking, 3(1), 69.

Kinderman, P., Schwannauer, M., Pontin, E., \& Tai, S. (2011). The development and validation of a general measure of well-being: the BBC well-being scale. Quality of Life Research, 20(7), 1035-1042.

Kumaraswamy, S., \& Shetty, P. K. (2016). Critical abiotic factors affecting implementation of technological innovations in rice and wheat production: A review. Agricultural Reviews, 37(4), 268-278.

Lago, S., Cantarero, D., Rivera, B., Pascual, M., Blázquez-Fernández, C., Casal, B., \& Reyes, F. (2018). Socioeconomic status, health inequalities and non-communicable diseases: a systematic review. Journal of Public Health, 26(1), 1-14.

Lee, J. M., Lee, J., \& Kim, K. T. (2020). Consumer financial well-being: Knowledge is not enough. Journal of Family and Economic Issues, 41(2), 218-228.

Legrand, B., Perraut, A., Herath, C. S., Wijekoon, R., \& Perera, L. (2018). The most frequent agronomic practices used by the coconut farmers in the "Coconut Triangle" of Sri Lanka. Cord, 34(2), 42-48.

Liliane, T. N., \& Charles, M. S. (2020). Factors affecting yield of crops. Agronomy-Climate Change \& Food Security, 9. 
Mien, T., \& Said, R. (2018). A cross-sectional household analysis of household consumption patterns: An indirect approach to identify the possible factors of personal bankruptcy. Jurnal Ekonomi Malaysia, 52(3), 231-246.

Nga, K. H., \& Yeoh, K. K. (2015). Affective, social and cognitive antecedents of attitude towards money among undergraduate students: A Malaysian study. Pertanika Journal of Social Sciences \& Humanities, 23.

Ntshangase, N. L., Muroyiwa, B., \& Sibanda, M. (2018). Farmers' perceptions and factors influencing the adoption of no-till conservation agriculture by small-scale farmers in Zashuke, KwaZulu-Natal province. Sustainability (Switzerland), 10(2).

OECD. (2011). Development co-operation report 2011. Retrieved on 31/08/2021 from https://www.oecd.org/dac/developmentco-operationreport2011.htm.

OECD. (2013). "Economic well-being", in OECD framework for statistics on the distribution of household income, consumption and wealth. Retrieved on 31/08/2021 from https://doi.org/10.1787/ 9789264194830-5-en.

Orsila, R., Luukkaala, T., Luukkaala, T., Manka, M. L., \& Nygard, C. H. (2011). A new approach to measuring work-related well-being. International Journal of Occupational Safety and Ergonomics, 17(4), 341-359.

Osberg, L., \& Sharpe, A. (2002). An index of economic well-being for selected OECD countries. Review of Income and Wealth, 48(3), 291-316.

Poh, L. M., Sabri, M. F., Wahab, H. A. R. A., \& Wijekoon, R. (2021). Determinants of financial vulnerability among civil servants in Peninsular Malaysia. Malaysian Journal of Consumer and Family Economics, 27, 113-143.

Radzyk, J. (2014). Validation of a new social well - being questionnaire. 18-21.

Rai, K., Dua, S., \& Yadav, M. (2019). Association of financial attitude, financial behavior and financial knowledge towards financial literacy: A structural equation modeling approach. FIIB Business Review, 8(1), 51-60.

Rajna, A., \& Sabri, M. F. (2015). Financial management practices of medical practitioners in the private and public medical service in Malaysia. International Review of Management and Business Research, 4(4), 1105-1117.

Rimple, M., \& Taneja, M. (2012). Money attitude - An abridgement. Journal of Arts, Science \& Commerce, 3(3), 94-98.

Robb, C. A., \& Woodyard, A. S. (2011). Financial knowledge and best practice behavior, 22(1), 60-70.

Sabri, M. F., Juen, T. T., Othman, M. A., \& Rahim, H. A. (2015). Financial literacy, financial management practices, and retirement confidence among women working in government agencies: A mediation model. The Journal of Developing Areas, 49(6), 405412.

Sabri, M. F., \& Falahati, L. F. (2013). Predictors of financial well-being among Malaysian employees: Examining the mediate effect of financial stress. Journal of Emerging Economies and Islamic Research, 1(3), 61-76.

Sabri, M. F., Abd Rahim, H., Wijekoon, R., Fardini, N., Zakaria, A. S. M., \& Reza, T. S. (2020b). The mediating effect of money attitude on association between financial literacy, financial behavior, and financial vulnerability, International Journal of Academic Research in Business and Social Sciences, 10(15), 340-358.

Sabri, M. F., Reza, T. S., \& Wijekoon, R. (2020a). Financial management, savings and investment behavior and financial well-being of working women in the public sector. Majalah Ilmiah Bijak, 17(2), 135-153. 
Sabri, M. F., \& Wijekoon, R. (2019). The influence of gender and ethnicity on young adults' participation in financial education programme. Journal of Management and Sustainability, 9(1), 159-170.

Sabri, M. F., Wijekoon, R., \& Rahim, H. A. (2020c). The influence of money attitude, financial practices, self-efficacy and emotion coping on employees' financial well-being. Management Science Letters, 10(4), 889-900.

Sabri, M. F., Wijekoon, R., Ramli, N. N., \& Dass, T. M. (2019). The impact of smart money kit on children's financial knowledge, attitude and behavior. Journal of Social Sciences and Humanities, 3, 48-59.

Sabri, M. F., \& Zakaria, N. F. (2015). The influence of financial literacy, money attitude, financial strain and financial capability on young employees' financial well-being. Pertanika Journal of Social Sciences \& Humanities, 23(4), 827-848.

Sehrawat, K., Vij, M., \& Talan, G. (2021). Understanding the Path toward financial well-being: Evidence from India. Frontiers in Psychology, 12(July). Retrieved from https://doi.org/10.3389/ fpsyg.2021.638408.

Shareef, M. A., Kumar, V., Kumar, U., \& Dwivedi, Y. K. (2011). E-government adoption model (GAM): Differing service maturity levels. Government Information Quarterly, 28(1), 1735.

Smale, M., \& Mason, N. (2014). Hybrid seed and the economic well-being of smallholder maize farmers in Zambia. Journal of Development Studies, 50(5), 680-695.

Theis, S., Lefore, N., Meinzen-Dick, R., \& Bryan, E. (2018). What happens after technology adoption? Gendered aspects of small-scale irrigation technologies in Ethiopia, Ghana, and Tanzania. Agriculture and Human Values, 35(3), 671-684.

Topa, G., Hernández-Solís, M., \& Zappalà, S. (2018). Financial management behavior among young adults: The role of need for cognitive closure in a three-wave moderated mediation model. Frontiers in Psychology, 9(NOV), 1-10.

Wijekoon, R., Sabri, M. F., \& Paim, L. (2021). Poverty: A literature review of the concept, measurements, causes and the way forward. International Journal of Academic Research in Business and Social Sciences, 11(15), 39-111.

Wu, H., Ding, S., Pandey, S., \& Tao, D. (2010). Assessing the impact of agricultural technology adoption on farmers' well-being using propensity-score matching analysis in rural china. Asian Economic Journal, 24(2), 141-160.

Xiao, J. J. (2013). Family economic well-being. In Handbook of marriage and the family (pp. 573-611). Springer, Boston, MA.

Zulfiqar, M., \& Bilal, M. (2016). Financial wellbeing is the goal of financial literacy. Research Journal of Finance and Accounting, 7(11), 94-103. 